\section{Growth and Ion Distribution Is Affected by Irrigation with Saline Water in Selected Landscape Species Grown in Two Consecutive Growing Seasons: Spring-summer and Fall-winter}

\author{
Luis A. Valdez-Aguilar ${ }^{1,2}$ and Catherine M. Grieve \\ U.S. Department of Agriculture, Agricultural Research Service, U.S. Salinity \\ Laboratory, 450 West Big Springs Road, Riverside, CA 92507
}

Abdul Razak-Mahar
Department of Botany, Shah Abdul Latif University, Khairpur, Sindh, Pakistan

Milton E. McGiffen and Donald J. Merhaut

Department of Plant Sciences, University of California, Riverside, CA 925210124

Additional index words. boxwood, escallonia, hawthorn, hibiscus, juniper, salt partitioning, visual quality

\begin{abstract}
Landscape irrigation is the second largest user of reclaimed water in industrialized countries; however, its high concentration of soluble salts, especially $\mathrm{Na}^{+}$and $\mathrm{Cl}^{-}$, may induce growth reduction and leaf necrosis or bronzing in ornamental species. The present study was conducted to determine the growth and quality responses and nutritional ion imbalances of selected landscape species during the container production phase when subjected to irrigation with water of increasing $\mathrm{NaCl}+\mathrm{CaCl}_{2}$ concentrations. Plants of boxwood [Buxus microphylla var. japonica (Mull. Arg. ex Miq) Rehder \& E.H. Wilson], escallonia (Escallonia $\times$ exoniensis hort. Veich ex Bean), hawthorn [Raphiolepis indica (L.) Lind. Ex Ker Gawl. × 'Montic'], hibiscus (Hibiscus rosa-sinensis L.), and juniper (Juniperus chinensis L.) were grown in a greenhouse in the Spring-Summer and in the Fall-Winter in separate experiments. Saline irrigation consisted of solutions with electrical conductivities $\left(\mathrm{EC}_{\mathrm{iw}}\right)$ of $0.6,2,4,6$, and $8 \mathrm{dS} \cdot \mathrm{m}^{-1}$ in the Spring-Summer experiment and $0.6,4,6,8$, and 12 dS $\cdot \mathrm{m}^{-1}$ in the Fall-Winter. Growth of the five species decreased when irrigated with saline waters. Leaf growth was highly sensitive to salinity and the average decrease in leaf dry weight was the criterion used to rank the tolerance of the species. In the Spring-Summer experiment, the ranking was (higher tolerance to lower tolerance): juniper $\sim$ boxwood $>$ escallonia $>$ hawthorn $>$ hibiscus, whereas in Fall-Winter, the ranking was: juniper boxwood $>$ hibiscus $>$ escallonia $>$ hawthorn. The species were ranked according to their visual attractiveness in the Spring-Summer experiment. The threshold $\mathrm{EC}_{\mathrm{iw}}$ at which visual attractiveness was affected gave the following ranking (higher to lower tolerance): hibiscus $>$ juniper $>$ escallonia $>$ hawthorn $>$ boxwood. Estimating the EC of drainage water from threshold $\mathrm{EC}_{\mathrm{iw}}$, boxwood was classified as sensitive, hawthorn as moderately sensitive, escallonia as moderately tolerant, and hibiscus and juniper as highly tolerant. Tolerance of juniper was ascribed to $\mathrm{Na}^{+}$and $\mathrm{Cl}^{-}$retention in the roots observed in both growing seasons and to the higher root biomass that allowed a higher accumulation of salts in this organ, preventing translocation to the leaves. Although boxwood exhibited acceptable tolerance in terms of growth, visual quality severely decreased; in contrast, growth of hibiscus was the most severely reduced but was rated as the most tolerant species in terms of visual quality. This opposite response may be the result of an excellent capacity to compartmentalize salts in hibiscus, whereas in boxwood, this mechanism may be absent.
\end{abstract}

\footnotetext{
Received for publication 3 Dec. 2010. Accepted for publication 21 Jan. 2011.

Mention of company names or products is for the benefit of the reader and does not imply endorsement, guarantee, or preferential treatment by the USDA or its agents.

${ }^{1}$ Current address: Centro de Investigación en Química Aplicada, Blvd. Enrique Reyna Hermosillo 140, Saltillo, Coah., México 25253.

${ }^{2}$ To whom reprint requests should be addressed; e-mail lavaldez@ciqa.mx.
}

Conservation of water is a critical issue worldwide in the arid and semiarid regions. Water of good quality is predicted to become scarcer as a result of competition among a rapidly increasing urban population and industrial development (Niu and Rodriguez, 2006). Many cities and districts have trouble balancing water demands of agricultural, landscape, industrial, and domestic users (Qian and Mechan, 2005). Irrigation of the increasing urban landscapes associated with urban settings
(Loram et al., 2007) consumes large quantities of water. For example, in the arid Mountain West of the United States, landscape irrigation is estimated to account for up to $50 \%$ of the municipal yearly water used during the spring to fall season (Kjelgren et al., 2000). Other estimations indicate that in cities in the desert of the southwestern United States, landscape irrigation consumes up to $90 \%$ of all the water used by a single family (Sovocool et al., 2006).

According to Qian and Mechan (2005), the population increase has also increased the volume of wastewater generated, which, once recycled or treated and used for irrigation, is viewed as one of the approaches to maximize the existing water resources. Landscape irrigation is the second largest user of reclaimed water in industrialized countries (Asano, 2002). Recycled or wastewater is a valuable resource that may mitigate the use of potable water for irrigation purposes. However, reclaimed water represents a significant concern for plant production and performance in the landscape because it may be high in soluble salts (Ammary, 2007), which may increase salinity of soil or growing medium (Lindsey et al., 1998), thus limiting its use for landscape irrigation (Zollinger et al., 2007). Salinity may affect the growth of ornamental shrubs by reducing stem growth and leaf expansion resulting from osmotic effects or by toxicity resulting from high ionic concentration of constituents such as $\mathrm{Na}^{+}$and $\mathrm{Cl}^{-}$, typical of reclaimed wastewater (USEPA, 1992). Excessive $\mathrm{Na}^{+}$and $\mathrm{Cl}^{-}$concentration in plant tissues may reduce visual quality of ornamental plants by inducing leaf necrosis or bronzing. However, in ornamental horticulture, short-stature plants are not necessarily associated with poor quality as demonstrated in marigold (Valdez-Aguilar et al., 2009). The use of salt-tolerant species is a viable option that should be considered in landscaping projects (Cassaniti et al., 2009). Species that maintain acceptable growth rates and that also possess mechanisms to exclude $\mathrm{Na}^{+}$and $\mathrm{Cl}^{-}$from transport to sensitive organs and that still remain attractive despite irrigation with saline water are ideal for landscaping under such conditions. The present study was conducted to determine the growth and visual quality responses and nutritional ion imbalances of selected landscape shrub species subjected to irrigation with water of increasing $\mathrm{NaCl}+\mathrm{CaCl}_{2}$ concentrations during container production.

Table 1. Salts used to increase electrical conductivity of water $\left(\mathrm{EC}_{\mathrm{iw}}\right)$ for irrigation of plants of five selected ornamental species grown during the spring-summer $\left(0.6,2,4,6\right.$, and $\left.8 \mathrm{dS} \cdot \mathrm{m}^{-1}\right)$ or the fall-winter seasons $(0.6,4,6,8$, and $\left.12 \mathrm{dS} \cdot \mathrm{m}^{-1}\right)$.

\begin{tabular}{lcc}
\hline $\mathrm{EC}_{\text {iw }}\left(\mathrm{dS} \cdot \mathrm{m}^{-1}\right)$ & $\mathrm{NaCl}\left(\mathrm{mg} \cdot \mathrm{L}^{-1}\right)$ & $\mathrm{CaCl}_{2}\left(\mathrm{mg} \cdot \mathrm{L}^{-1}\right)$ \\
\hline 0.6 & 0 & 0 \\
2 & 420 & 420 \\
4 & 1000 & 1000 \\
6 & 1630 & 1630 \\
8 & 2230 & 2230 \\
12 & 3434 & 3434
\end{tabular}


Boxwood

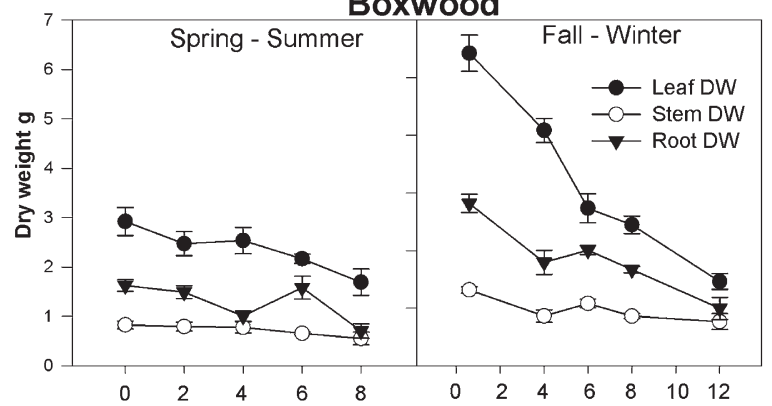

Escallonia

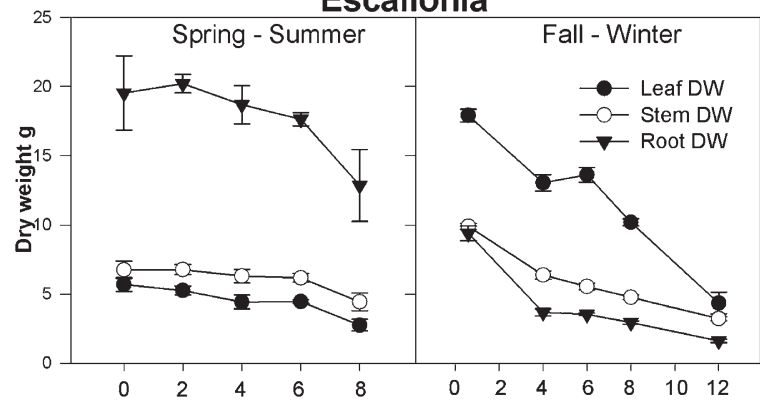

Hibiscus

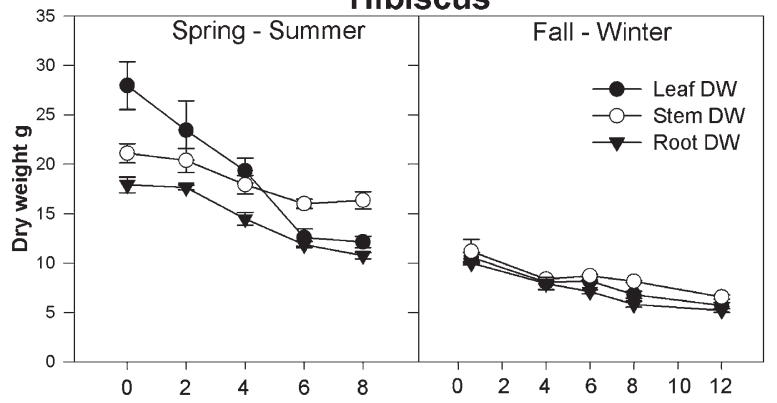

Hawthorn

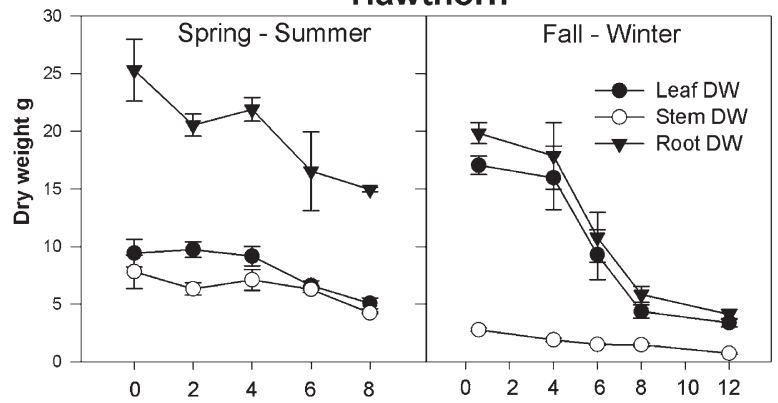

Juniper

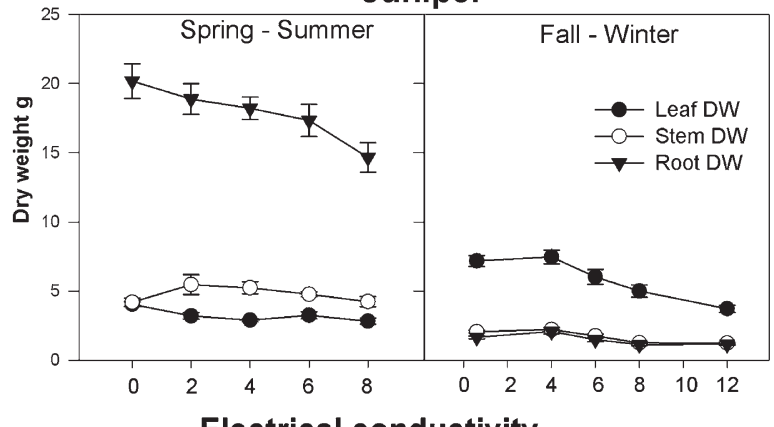

Electrical conductivity dS $\mathbf{m}^{-1}$

Fig. 1. Leaf, stem, and root dry weight (DW) produced by selected landscape ornamental species in response to irrigation with water of increasing electrical conductivity and cultivation during the spring-summer or fall-winter seasons. Bars represent SEM $(n=5)$.

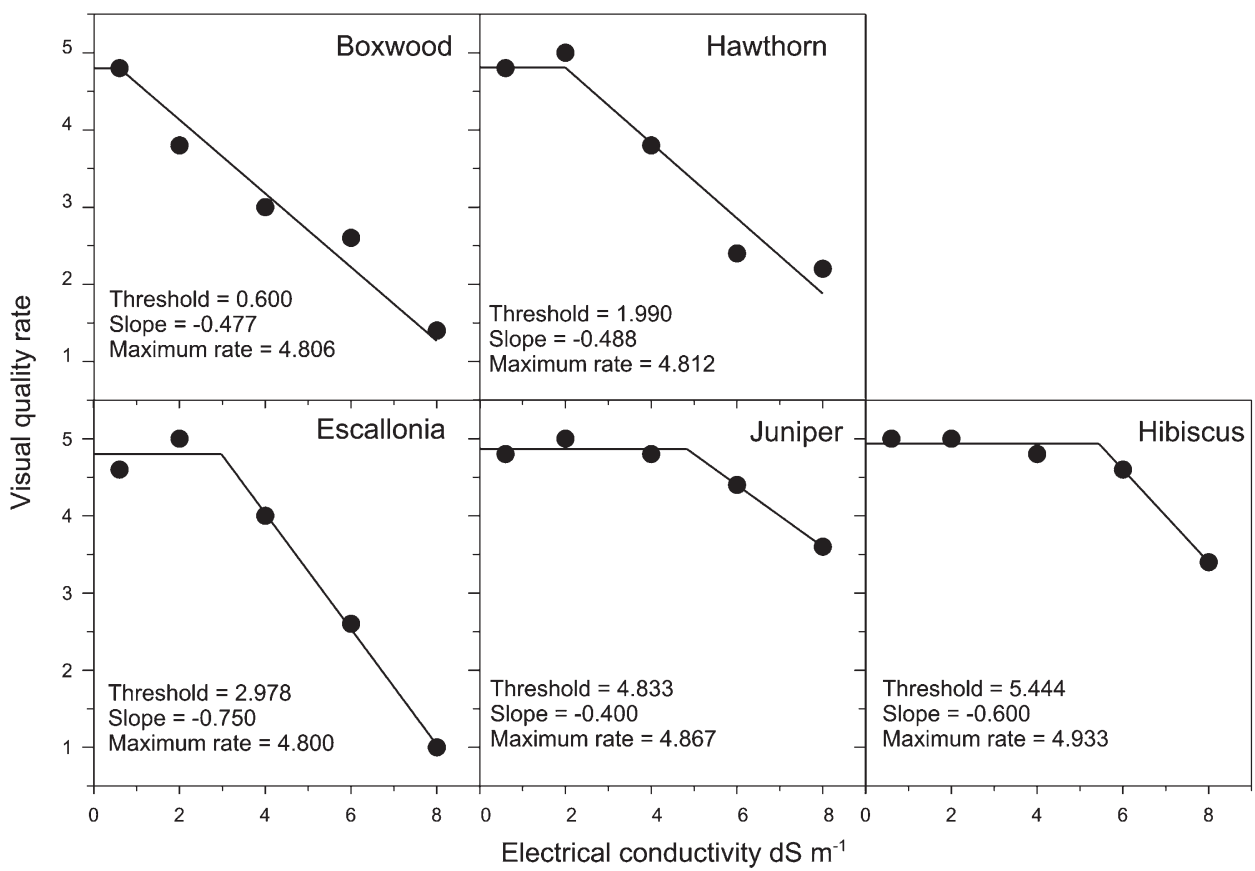

Fig. 2. Visual quality rating for five selected landscape ornamental species as affected by irrigation with water of increasing electrical conductivity and cultivated during the spring-summer season. Highest quality $=5$. Lowest quality $=1$. 


\section{Materials and Methods}

Spring-summer experiment. Plants of boxwood [Buxus microphylla var. japonica (Mull. Arg. ex Miq) Rehder \& E.H. Wilson 'Green Beauty'], escallonia (Escallonia xexoniensis hort. Veich ex Bean 'Fradesii'), hawthorn [Raphiolepis indica (L.) Lind. Ex Ker Gawl. $\times$ 'Montic'], hibiscus (Hibiscus rosa sinensis L. 'Brilliant'), and juniper (Juniperus chinensis L. 'Torulosa') were grown in greenhouses at the U.S. Salinity Laboratory, in Riverside, CA. Liners 4 to 5 inches tall were transplanted on 18 May 2007 into 4-L pots containing a mixture of sand:composted pine bark $(0.5: 0.5 \mathrm{v} / \mathrm{v})$ as the growing medium.

Growing medium, $\mathrm{pH}$ 6.8, was supplemented with $10 \mathrm{~g}$ per pot of 14-14-14 Osmocote slow-release fertilizer (Scotts MiracleGro Co., Marysville, OH). Standard meteorological measurements were recorded hourly in the greenhouse with a Class I agrometeorological station. Air temperature ranged from 13.1 to $45.4{ }^{\circ} \mathrm{C}$ (average, $24.8^{\circ} \mathrm{C}$ ), relative humidity ranged from $37.1 \%$ to $46.1 \%$ (average, $42.4 \%$ ), and average photosynthetic active radiation $(P A R)$ was $395.8 \mu \mathrm{mol} \cdot \mathrm{m}^{-2} \cdot \mathrm{s}^{-1}$, whereas noontime average $P A R$ was $780.2 \mu \mathrm{mol} \cdot \mathrm{m}^{-2} \cdot \mathrm{s}^{-1}$.

Saline irrigation, imposed 1 week after transplant, consisted of solutions with added $\mathrm{NaCl}+\mathrm{CaCl}_{2}$ to give the following $\mathrm{EC}_{\mathrm{iw}}$ : 0.6, $2,4,6$, and $8 \mathrm{dS} \cdot \mathrm{m}^{-1}$ (Table 1 ). Irrigation solutions ( $\mathrm{pH} 6.5$ ), prepared with nanopure water, also contained $40 \mathrm{mg} \cdot \mathrm{L}^{-1}$ magnesium, $50 \mu \mathrm{M}$ iron (as sodium ferric diethylenetriamine pentacetate), $23 \mu \mathrm{M} \mathrm{H}_{3} \mathrm{BO}_{4}, 5 \mu \mathrm{M} \mathrm{MnSO} 4,0.4$ $\mu \mathrm{M} \mathrm{ZnSO}, 0.2 \mu \mathrm{M} \mathrm{CuSO}$, and $0.1 \mu \mathrm{M}$ $\mathrm{H}_{2} \mathrm{MoO}_{4}$. Each treatment was replicated five times and experimental units with one plant were distributed randomly in the greenhouse. Irrigation water was applied as needed with a volume enough to obtain a $30 \%$ to $35 \%$ leaching fraction.

Plants were harvested 84 (boxwood), 109 (escallonia), 133 (juniper and hawthorn), or 138 (hibiscus) d after transplanting. At harvest time, plants were visually rated to determine their ornamental attributes using a 1 (poor quality, leaf bronzing higher than $75 \%$ or dead plants) to 5 (best quality, no leaf bronzing) scale by a four-person panel. Attributes such as leaf bronzing, leaf scorching, and overall appearance were considered. Harvested plants were separated into roots, stems, and leaves and washed twice in nanopure water, bagged, and placed in an oven at $70{ }^{\circ} \mathrm{C}$ for $72 \mathrm{~h}$. Dry weight (DW) was recorded and plant organs were ground in a Wiley Mill to pass a 20-mesh screen $\left(20\right.$ holes per inch $\left.{ }^{2}\right)$. Leaf, stem, and root $\mathrm{Ca}^{2+}, \mathrm{Na}^{+}$, and $\mathrm{K}^{+}$were determined on nitricperchloric acid digests by ICPOES (PerkinElmer Corp., Waltham, MA), whereas $\mathrm{Cl}^{-}$was analyzed on nitric-acetic acid extracts by coulometric-amperometric titration. Dry weight, $\mathrm{Ca}^{2+}, \mathrm{K}^{+}, \mathrm{Na}^{+}$, and $\mathrm{Cl}^{-}$partitioning into leaves, stems, and roots as well as the shoot/root ratio were calculated. At experiment termination, drainage water after the last irrigation was captured and leachate EC was measured. Data recorded were analyzed with SAS Version 8.02 (SAS Institute, Inc. 2001) as a one-way analysis of variance and means were separated by Tukey's procedure at $P<0.05$. Linear and/or quadratic trends were also estimated. Visual quality rating was analyzed using the piecewise linear response function as proposed by van Genuchten (1983); the function contains three independent parameters: 1) the nonsaline control quality rate; 2) the salinity threshold (the maximum salinity without quality rate reduction as compared with nonsaline conditions); and 3) the slope (the fractional quality rate decline per unit increase in salinity beyond the threshold).
Fall-winter experiment. The fall-winter experiment was established with liners with the same characteristics, species, and cultivars listed previously. Containers and growing medium preparation were as described for the spring-summer experiment. Plants were potted on 27 Sept. 2007 and treatments were imposed $5 \mathrm{~d}$ later. Air temperature ranged from 12.1 to $38.1{ }^{\circ} \mathrm{C}$ (average, $24.7{ }^{\circ} \mathrm{C}$ ), relative humidity ranged from $39.1 \%$ to $44.9 \%$ (average, $42.1 \%$ ), and average $P A R$ was $279.7 \mu \mathrm{mol} \cdot \mathrm{m}^{-2} \cdot \mathrm{s}^{-1}$ (noontime average $P A R$ was $\left.612.1 \mu \mathrm{mol} \cdot \mathrm{m}^{-2} \cdot \mathrm{s}^{-1}\right)$.
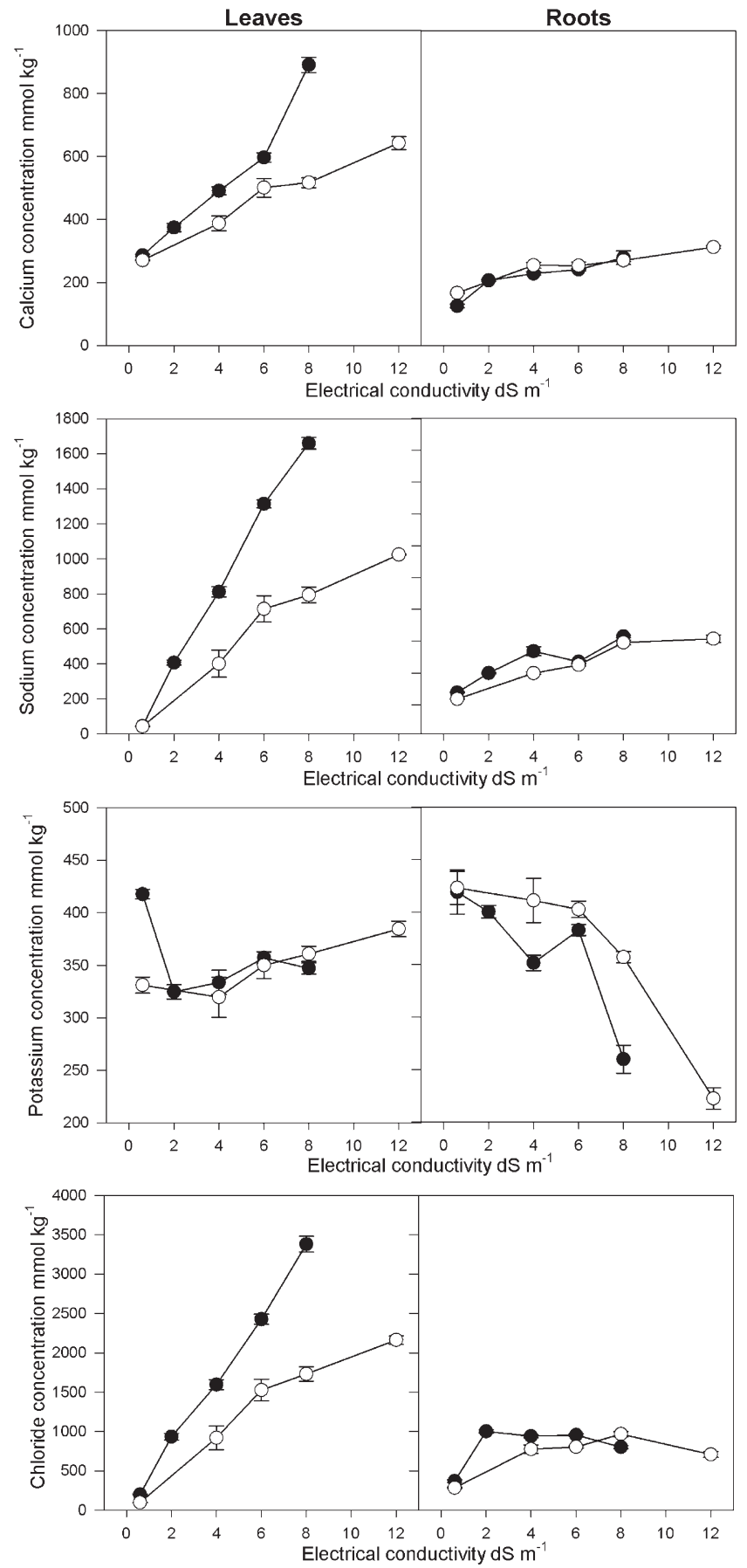

Fig. 3. Calcium, sodium, potassium, and chloride concentration in leaves and roots of boxwood plants cultivated during the spring-summer and fall-winter seasons under irrigation with water of increasing electrical conductivity. Bars represent SEM $(n=5)$. 
Saline irrigation consisted of solutions prepared as indicated in the previous experiment to give the following $\mathrm{EC}_{\mathrm{iw}}$ : $0.6,4,6,8$, and 12 $\mathrm{dS} \cdot \mathrm{m}^{-1}$ (Table 1). At the end of the experiment, substrate samples were taken and air-dried for $3 \mathrm{~d}$. Irrigation solutions had a $\mathrm{pH}$ and micronutrient concentration as indicated for the previous experiment. Irrigation was applied as needed to obtain a $30 \%$ to $35 \%$ leaching fraction for each treatment. Plants were harvested 131 (boxwood), 160 (escallonia), 157 (juniper), 154 (hawthorn), and 167 (hibiscus) d after transplanting. Harvested plants were processed to measure DW of leaves, stems, and roots and to perform a mineral analysis as indicated in the previous experiment. Experimental design, number of replications, and statistical analysis were similarly conducted.

\section{Results}

Increasing $\mathrm{EC}_{\mathrm{iw}}$ resulted in a significant increase in $\mathrm{EC}_{\mathrm{dw}}$ at experiment termination in all the five species studied. Averaged across species and seasons, $\mathrm{EC}_{\mathrm{dw}}$ increased linearly as $\mathrm{EC}_{\mathrm{iw}}$ increased; regression model was $\mathrm{EC}_{\mathrm{dw}}=1.06+$ $1.95 \mathrm{EC}_{\mathrm{iw}}\left(R^{2}=0.799, P<0.001 ; \mathrm{n}=40\right)$.

Boxwood. Linear decreases in leaf, root, and stem DW were observed in boxwood when irrigated with water of increasing salinity
(Fig. 1). Leaf and root DW were higher in fallwinter plants compared with spring-summer plants, but increasing $\mathrm{EC}_{\mathrm{iw}}$ appears to have a more detrimental effect during the fallwinter season. Higher DW accumulation was observed only when plants were irrigated with water at low EC $\left(0.6\right.$ to $\left.4 \mathrm{dS} \cdot \mathrm{m}^{-1}\right)$. Growing season did not affect the shoot/root ratio; averaged across $\mathrm{EC}_{\mathrm{iw}}$, the shoot/root ratio of the spring-summer plants was $2.62 \pm$ 0.17 (average $\pm \mathrm{SE}$ ), whereas in fall-winter plants, it was $2.21 \pm 0.08$. Effects of increasing $\mathrm{EC}_{\mathrm{iw}}$ on plant growth were also reflected in the visual quality of plants (Fig. 2). As for the visual quality ranking, boxwood was rated as salt-sensitive because $0.6 \mathrm{dS} \cdot \mathrm{m}^{-1}$ was the threshold $\mathrm{EC}_{\mathrm{iw}}$ at which quality of plants decreased linearly.

Calcium, $\mathrm{Na}^{+}$, and $\mathrm{Cl}^{-}$were higher in the leaves than in the roots but the concentrations of these ions increased in both leaves and roots as $\mathrm{EC}_{\mathrm{iw}}$ increased (Fig. 3). However, $\mathrm{Ca}^{2+}, \mathrm{Na}^{+}$, and $\mathrm{Cl}^{-}$were more concentrated in the leaves of plants grown during the spring-summer, whereas in the roots, the concentration of these ions was unaffected by the growing season. In general, leaf $\mathrm{K}^{+}$was unaffected by $\mathrm{EC}_{\mathrm{iw}}$ but root $\mathrm{K}^{+}$decreased as $\mathrm{EC}_{\mathrm{iw}}$ increased regardless of the growing season (Fig. 3). Allocation of $\mathrm{Ca}^{2+}$ (Fig. 4), $\mathrm{Na}^{+}$(Fig. 5), and $\mathrm{Cl}^{-}$(Fig. 6) was predominantly to the leaves in both growing seasons; however, allocation of $\mathrm{Na}^{+}$and $\mathrm{Cl}^{-}$decreased in the roots and increased in the leaves and stems of plants grown in the spring-summer as $\mathrm{EC}_{\mathrm{iw}}$ increased. Similar response was detected for $\mathrm{Cl}^{-}$in the fall-winter (Fig. 6).

Hawthorn. Growth of hawthorn decreased linearly with increasing $\mathrm{EC}_{\mathrm{iw}}$ when planted in the spring-summer, whereas the decrease was quadratic, at least for roots and leaves, in the fall-winter (Fig. 1). Roots of hawthorn showed larger DW accumulation than other plant parts in the spring-summer, whereas in the fallwinter, this tendency was also observed but leaf DW was comparable to that of roots (Fig. 1). Growing season had a marked effect on the shoot/root ratio; averaged across $\mathrm{EC}_{\mathrm{iw}}$, in spring-summer plants, the shoot/root ratio was lower $(0.821 \pm 0.13)$ than that of fallwinter plants $(10.01 \pm 1.64)$.

Sensitivity to irrigation water of increasing EC was also observed as a decrease in visual attributes of plants (Fig. 2); according to segmented analysis, visual value of hawthorn was not compromised when $\mathrm{EC}_{\mathrm{iw}}$ was as high as $1.99 \mathrm{dS} \cdot \mathrm{m}^{-1}$. However, higher $\mathrm{EC}_{\mathrm{iw}}$ was associated with a linear reduction in plant visual quality. The slope in the linear reduction phase was comparable to that of boxwood.
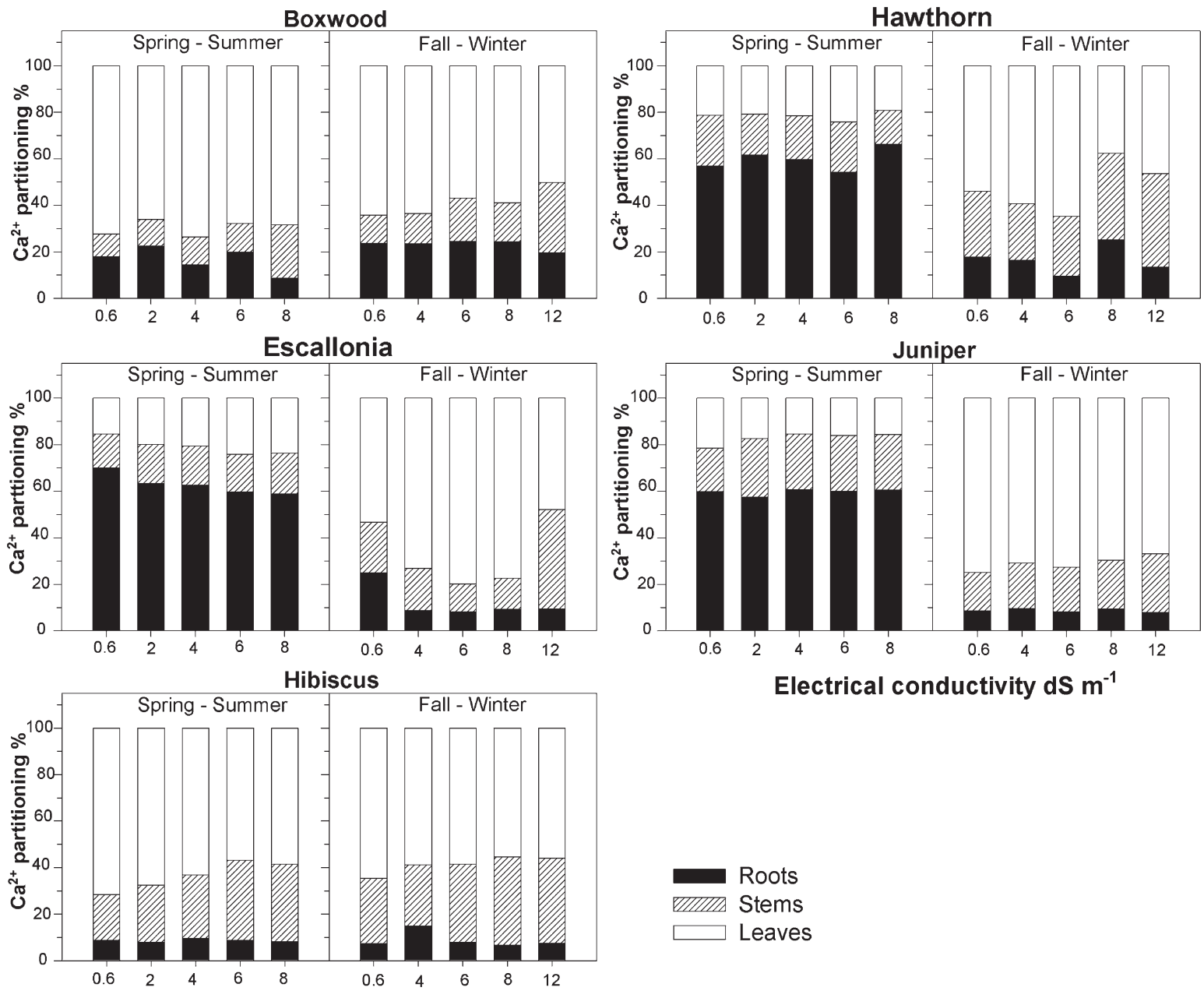

Roots

Stems

Leaves

Fig. 4. Calcium partitioning into roots, stems, and leaves in five selected landscape ornamental species as affected by irrigation with water of increasing electrical conductivity and cultivated during the spring-summer or fall-winter seasons. 

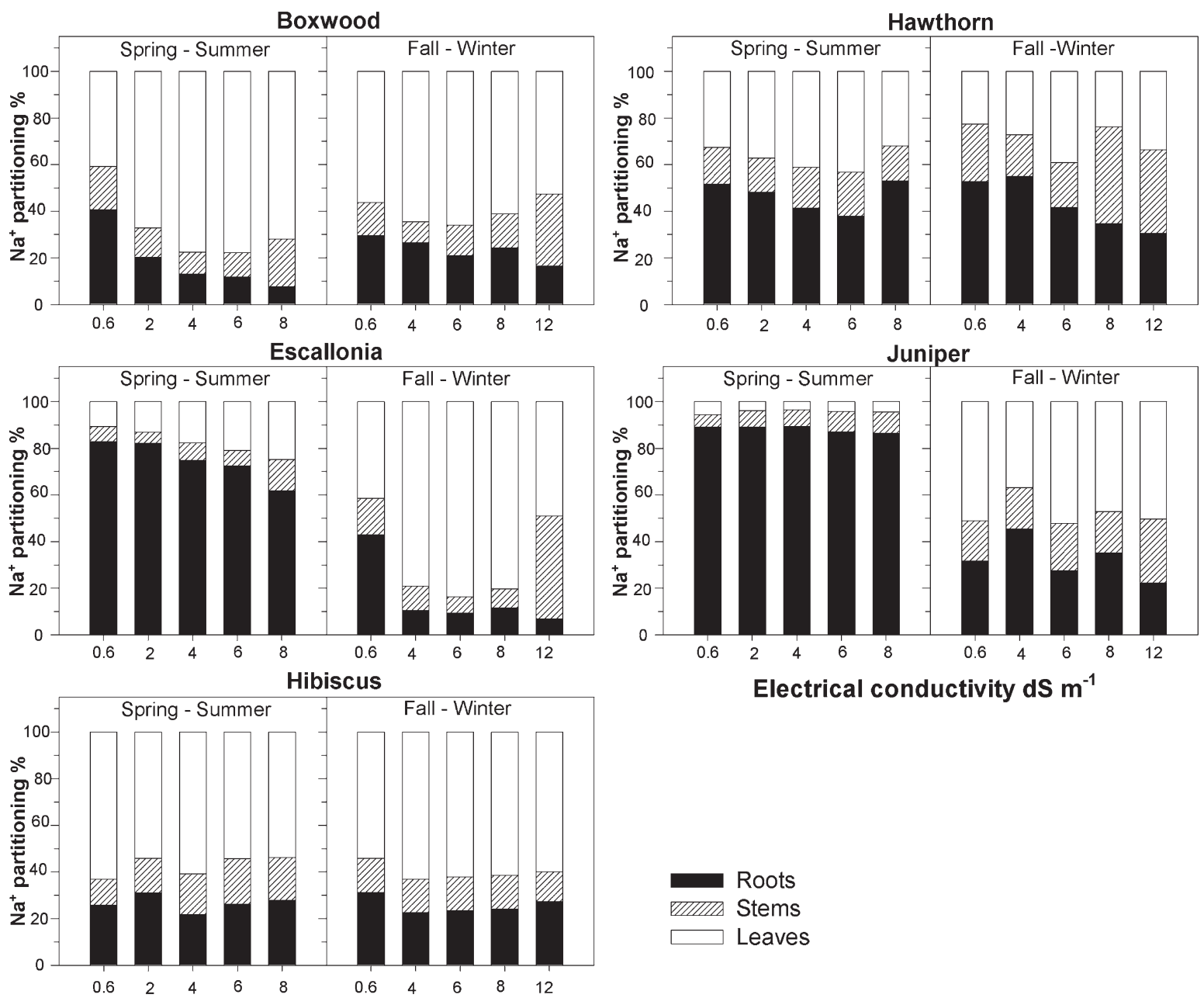

Fig. 5. Sodium partitioning into roots, stems, and leaves in five selected landscape ornamental species as affected by irrigation with water of increasing electrical conductivity and cultivated during the spring-summer season or fall-winter seasons.

Calcium, $\mathrm{Na}^{+}$, and $\mathrm{Cl}^{-}$concentration increased in the leaves and roots regardless of the growing season (Fig. 7); however, the increase in leaf ion concentration was greater during the fall-winter when $\mathrm{EC}_{\mathrm{iw}}$ was $8 \mathrm{dS} \cdot \mathrm{m}^{-1}$ or higher. Sodium and $\mathrm{Cl}^{-}$were more concentrated in the roots of plants grown in the spring-summer than in plants grown in the fall-winter, except when $\mathrm{EC}_{\mathrm{iw}}$ was $8 \mathrm{dS} \cdot \mathrm{m}^{-1}$ or higher. Calcium concentration was higher in the leaves than in the roots in both growing seasons. Potassium leaf and root concentration decreased linearly as $\mathrm{EC}_{\mathrm{iw}}$ increased, but $\mathrm{K}^{+}$was more concentrated in the leaves of plants grown in the spring-summer than in plants grown in the fall-winter.

Hawthorn exhibited differential allocation of $\mathrm{Ca}^{2+}$ and $\mathrm{Cl}^{-}$according to growing season. In plants grown in the spring-summer, $\mathrm{Ca}^{2+}$ (Fig. 4) and $\mathrm{Cl}^{-}$(Fig. 6) were preferentially accumulated in the roots, whereas in fall-winter plants, more $\mathrm{Ca}^{2+}$ and $\mathrm{Cl}^{-}$were accumulated in the stems and leaves. Sodium allocation to the roots was higher in spring-summer plants with no marked effects of $\mathrm{EC}_{\mathrm{iw}}$; however, during the fall-winter, $\mathrm{Na}^{+}$was greater allocated to the stems at high $\mathrm{EC}_{\mathrm{iw}}$ (Fig. 5). In general, leaves of hawthorn accumulated less $\mathrm{Na}^{+}$during the fall-winter.
Escallonia. Growth decreased in escallonia in response to increasing $\mathrm{EC}_{\mathrm{iw}}$. Plants grown in the spring-summer accumulated higher DW in the roots, whereas fall-winter plants exhibited higher DW in the leaves (Fig. 1). The higher allocation of DW to the leaves made the effect of increasing $\mathrm{EC}_{\mathrm{iw}}$ seem more dramatic in fallwinter plants, suggesting higher sensitivity to salinity. Averaged across $\mathrm{EC}_{\mathrm{iw}}$, the shoot/root ratio in spring-summer plants was lower $(0.62$ $\pm 0.03)$ than that of fall-winter plants $(4.72 \pm$ 0.21 ). Visual quality rating in escallonia was unaffected when $\mathrm{EC}_{\mathrm{iw}}$ was less than 2.98 dS $\cdot \mathrm{m}^{-1}$ (Fig. 2), but higher $\mathrm{EC}_{\mathrm{iw}}$ caused a sharp decrease in plant quality. The slope in the linear reduction phase was higher than that of boxwood and hawthorn.

Leaf $\mathrm{Ca}^{2+}$ and $\mathrm{Cl}^{-}$concentration increased linearly in both spring-summer and fall-winter plants (Fig. 8); however, the rate of increase was higher in the fall-winter when EC was $4 \mathrm{dS} \cdot \mathrm{m}^{-1}$ or higher. Leaf $\mathrm{Na}^{+}$concentration increased linearly but there was no growing season effect. In general, $\mathrm{Ca}^{2+}, \mathrm{Na}^{+}$, and $\mathrm{Cl}^{-}$ concentration in the roots increased with increasing $\mathrm{EC}_{\mathrm{iw}}$, but the concentration of these ions was higher in the leaves than in the roots. Calcium, $\mathrm{Na}^{+}$, and $\mathrm{Cl}^{-}$concentrations were higher in spring-summer plants when com- pared with fall-winter plants. Potassium leaf concentration was unaffected in both springsummer and fall-winter plants, whereas roots exhibited a consistent decrease in $\mathrm{K}^{+}$concentration as $\mathrm{EC}_{\mathrm{iw}}$ increased.

Calcium (Fig. 4), $\mathrm{Na}^{+}$(Fig. 5), and $\mathrm{Cl}^{-}$ (Fig. 6) were allocated primarily to the roots in plants grown during the spring-summer; however, a small proportion of these ions was allocated to the leaves and stems as $\mathrm{EC}_{\mathrm{iw}}$ increased. In plants grown in the fall-winter, more $\mathrm{Ca}^{2+}, \mathrm{Na}^{+}$, and $\mathrm{Cl}^{-}$was allocated to the leaves when $\mathrm{EC}_{\mathrm{iw}}$ was increased up to $8 \mathrm{dS} \cdot \mathrm{m}^{-1}$ or to the stems and leaves when $\mathrm{EC}_{\mathrm{iw}}$ was $12 \mathrm{dS} \cdot \mathrm{m}^{-1}$.

Juniper. Growth of juniper exhibited similar responses to that of escallonia when grown in the spring-summer because the greater DW was accumulated in the roots than in the leaves and stems (Fig. 1). Leaves and stems of juniper grown in the spring-summer season were only slightly affected by increasing $\mathrm{EC}_{\mathrm{iw}}$. In general, plants grown in the fall-winter season showed decreased growth compared with spring-summer plants. Dry weight of leaves in fall-winter plants seemed to be more affected by increasing $\mathrm{EC}_{\mathrm{iw}}$ than in the spring-summer plants. In juniper, there was a marked growing season effect on the shoot/root ratio; averaged across $\mathrm{EC}_{\mathrm{iw}}$, the 

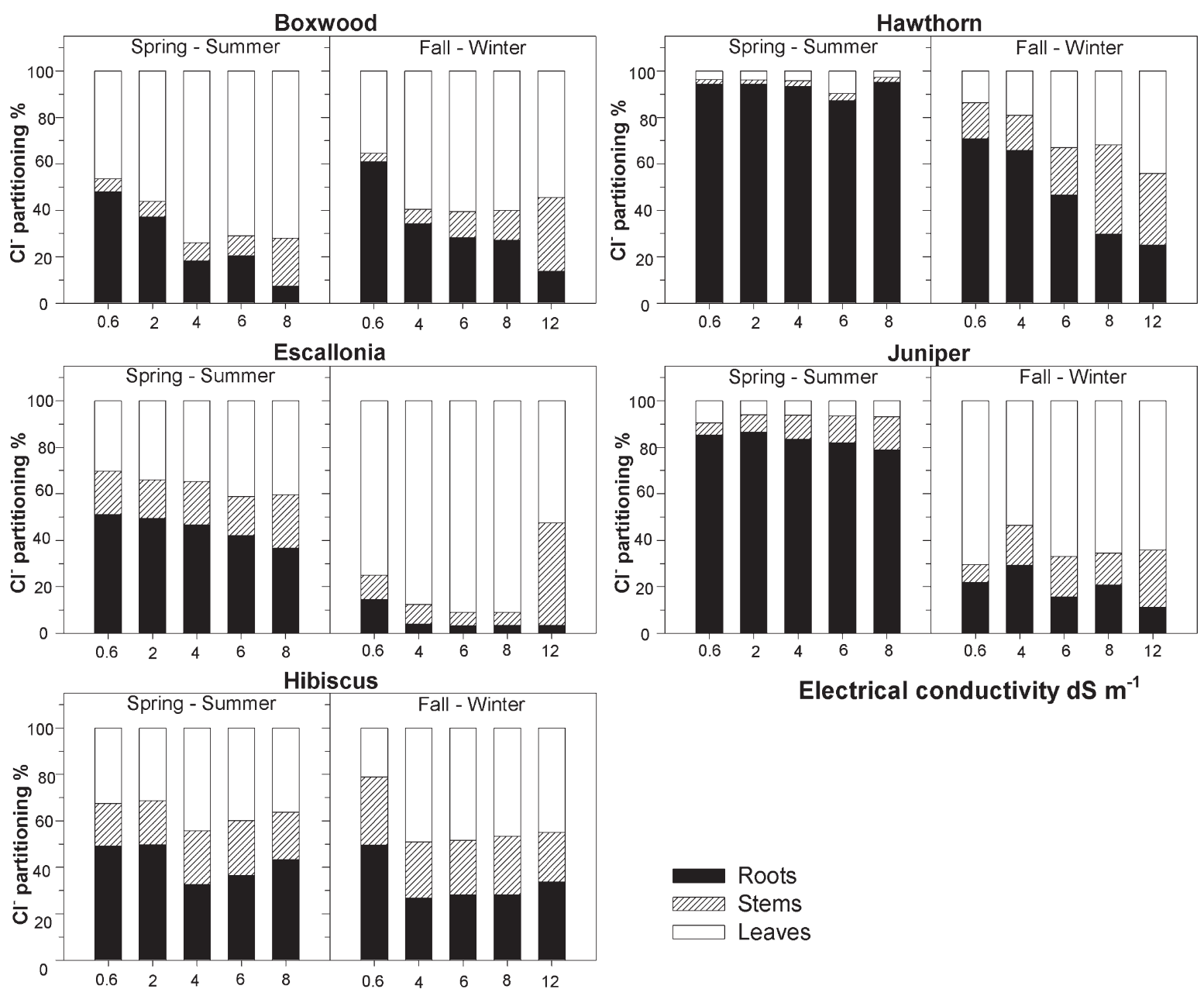

Electrical conductivity $\mathrm{dS}^{-1}$

Fig. 6. Chloride partitioning into roots, stems, and leaves in five selected landscape ornamental species as affected by irrigation with water of increasing electrical conductivity and cultivated during the spring-summer season or fall-winter seasons.

shoot/root ratio in spring-summer plants was $0.46 \pm 0.02$, whereas in fall-winter plants, it was $5.14 \pm 0.14$. Visual quality of juniper was unaffected as $\mathrm{EC}_{\mathrm{iw}}$ rose from 0.6 to $4.83 \mathrm{dS} \cdot \mathrm{m}^{-1}$ as estimated by segmented analysis (Fig. 2). Irrigation water of higher EC was associated with a linear decrease comparable to that of boxwood and hawthorn.

Calcium leaf concentration increased as $\mathrm{EC}_{\mathrm{iw}}$ increased; however, fall-winter plants exhibited higher $\mathrm{Ca}^{2+}$ concentration in the leaves than spring-summer plants (Fig. 9). Calcium concentration was lower in the roots than the leaves, and $\mathrm{Ca}^{2+}$ also increased with increasing salinity. Sodium concentration in leaves and roots increased with increasing $\mathrm{EC}_{\mathrm{iw}}$; however, $\mathrm{Na}^{+}$tended to be more concentrated in the roots than in the leaves in both spring-summer and fall-winter plants. Chloride was more concentrated in the roots of spring-summer plants, whereas $\mathrm{Cl}^{-}$concentration was similar in leaves and roots in fall-winter plants.

Growing season had an effect on $\mathrm{Ca}^{2+}, \mathrm{Na}^{+}$, and $\mathrm{Cl}^{-}$partitioning. In the spring-summer, $\mathrm{Ca}^{2+}$ (Fig. 4), $\mathrm{Na}^{+}$(Fig. 5), and $\mathrm{Cl}^{-}$(Fig. 6) were partitioned preferentially to the roots, whereas in fall-winter plants, these ions were allocated to the leaves. EC of irrigation water did not affect the partition of $\mathrm{Ca}^{2+}, \mathrm{Na}^{+}$, or $\mathrm{Cl}^{-}$.
Hibiscus. Hibiscus growth was limited during the fall-winter season but plants grown in the spring-summer exhibited higher DW in leaves, stems, and roots (Fig. 1). Regardless of the growing season, plant growth decreased in response to increasing $\mathrm{EC}_{\mathrm{iw}}$. Growing season did not affect the shoot/root ratio in hibiscus; averaged across $\mathrm{EC}_{\mathrm{iw}}$, the shoot/root ratio in spring-summer plants was $2.58 \pm 0.07$, whereas in fall-winter plants, it was $2.37 \pm$ 0.11 . Visual quality remained unaffected as $\mathrm{EC}_{\mathrm{iw}}$ increased from 0.6 to $5.44 \mathrm{dS} \cdot \mathrm{m}^{-1}$ (Fig. 2) but irrigation water of higher EC was associated with a linear decrease in quality comparable to that of escallonia.

Calcium, $\mathrm{Na}^{+}$, and $\mathrm{Cl}^{-}$increased linearly with increasing $\mathrm{EC}_{\mathrm{iw}}$ in the leaves of plants grown in both growing seasons (Fig. 10) as $\operatorname{did~} \mathrm{Na}^{+}$and $\mathrm{Cl}^{-}$in the roots. Calcium (Fig. 4), $\mathrm{Na}^{+}$(Fig. 5), and $\mathrm{Cl}^{-}$(Fig. 6) were allocated primarily to the leaves in both growing seasons; however, the amount of $\mathrm{Ca}^{2+}$ partitioned to the stems and the amount of $\mathrm{Cl}^{-}$distributed to the leaves increased in both seasons as $\mathrm{EC}_{\mathrm{iw}}$ increased.

\section{Discussion}

Plant growth of the five selected landscape ornamental species decreased when irrigated with increasingly saline waters. As stated by Munns and Tester (2008), growth reduction is one of the first signs of the osmotic effects that salinity imposes on plants. Under our experimental conditions, salinity of the growing medium increased twice as much as that of irrigation water as suggested by the estimated linear regression model. Thus, the salinity treatments imposed on plants were high enough to induce both osmotic and toxic effects on plants.

Increasing $\mathrm{EC}_{\mathrm{iw}}$ was associated with a predominantly linear decrease on DW accumulation of shoots and roots, and both plant parts were equally affected as suggested by the lack of a significant effect on the shoot/root ratio in all the five species studied (data not shown). However, growing season had a marked effect on the shoot/root ratio of some species. For example, the shoot/root ratio was much higher in escallonia, juniper, and hawthorn grown in the fall-winter season; thus, root growth was predominant during the spring-summer, whereas shoots exhibited higher growth during the fall-winter in these species. Shoot growth reduction was associated with a decreased elongation rate exhibited by all the landscape species evaluated (data not shown), probably as a result of the inhibition of lateral shoot development after several months of exposure to high salinity (Munns and Tester, 2008). 

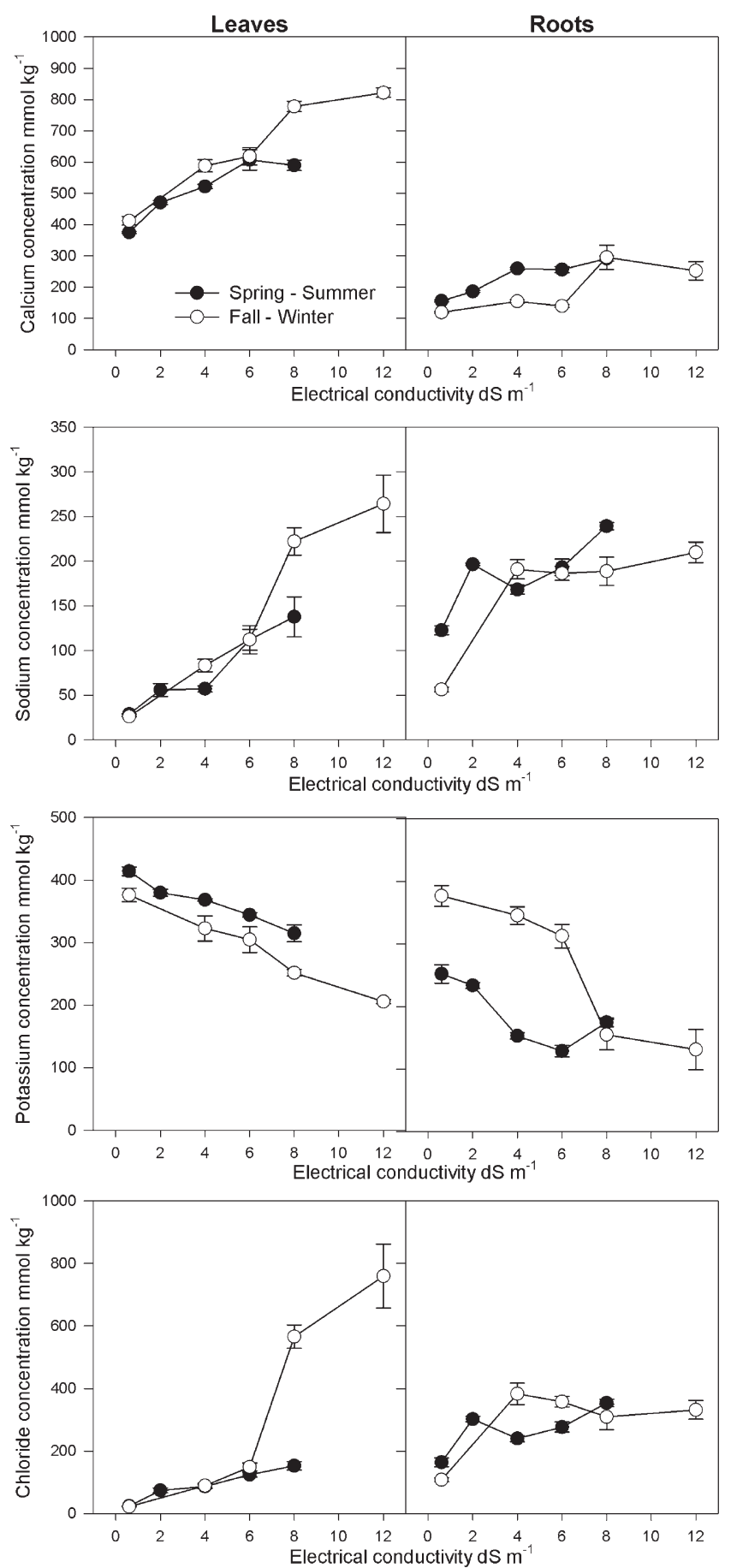

Fig. 7. Calcium, sodium, potassium, and chloride concentration in leaves and roots of hawthorn plants cultivated during the spring-summer and fall-winter seasons under irrigation with water of increasing electrical conductivity. Bars represent SEM $(n=5)$.

In general, $\mathrm{Ca}^{2+}$ concentration in the leaves of all the five species studied tended to increase with increasing $\mathrm{EC}_{\mathrm{iw}}$; roots also exhibited increased $\mathrm{Ca}^{2+}$ concentration but accumulation rate was much lower than that of leaves. Under saline irrigation, $\mathrm{Ca}^{2+}$ concentration in plant tissues is reported to either decrease or be unaffected (Niu and Rodriguez, 2006) as a result of competition with $\mathrm{Na}^{+}$(Wakeel et al., 2009) and/or the displacement of $\mathrm{Ca}^{2+}$ from the plasma membrane of root cells by high $\mathrm{Na}^{+}$ concentrations or external ionic interactions (Cramer et al., 1985). The increase in leaf
$\mathrm{Ca}^{2+}$ that we are reporting as $\mathrm{EC}_{\mathrm{iw}}$ increased was probably in response to the increase in $\mathrm{CaCl}_{2}$ in irrigation solution.

Leaves are highly sensitive to salinity because leaf growth rate decreases as a result of the osmotic effect around the roots that induces a decrease in water uptake and cell expansion leading to a lower appearance rate of new leaves and leaves of smaller size (Munns and Tester, 2008). Specific toxicity resulting from excess $\mathrm{Na}^{+}$and $\mathrm{Ca}^{2+}$ has also been ascribed as responsible for leaf growth reduction under saline irrigation (Munns and
Tester, 2008). Reduction in leaf expansion has been detected within minutes or hours after exposure of plants to high salinity in the growing medium (Munns, 2002). In the present experiments, the selected species under study were ranked in their salinity tolerance according to the slope of linear regression in models estimated to delineate the reduction in leaf $\mathrm{DW}$ as $\mathrm{EC}_{\mathrm{iw}}$ increased. The resulting ranking for the spring-summer experiment was as follows: $g$ of leaf DW reduction per $\mathrm{dS} \cdot \mathrm{m}^{-1}$.

$$
\begin{aligned}
& \begin{array}{l}
\text { Juniper } \sim \text { Boxwood }>\text { Escallonia }> \\
(-0.12) \quad(-0.14) \quad(-0.33)
\end{array} \\
& \text { Hawthorn }>\text { Hibiscus } \\
& (-0.59) \quad(-2.13)
\end{aligned}
$$

The ranking for plants grown in the Fall Winter season was as follows.

$$
\begin{aligned}
& \begin{array}{l}
\text { Juniper } \sim \text { Boxwood }>\text { Hibiscus }> \\
(-0.34) \quad(-0.35) \quad(-0.41)
\end{array} \\
& \text { Escallonia }>\text { Hawthorn } \\
& (-1.14) \quad(-1.38)
\end{aligned}
$$

According to the slopes as the sole criteria for defining tolerance to salinity, hibiscus would rank as the most sensitive species when grown in the spring-summer. This is in agreement to Black (2003) who rated hibiscus as a species with poor tolerance to salinity in Florida environments. Nonetheless, in the fallwinter season, hibiscus exhibited a slight tolerance, suggesting that it should be grown under saline irrigation only during the fallwinter season. Hibiscus exhibited comparable distribution of DW among plant organs in both seasons; likewise, $\mathrm{Ca}^{2+}, \mathrm{Na}^{+}$, and $\mathrm{Cl}^{-}$partitioning to plant organs was similar in both growing seasons. In addition, there was not a noticeable difference in $\mathrm{Ca}^{2+}, \mathrm{Na}^{+}$, or $\mathrm{Cl}^{-}$leaf concentration in either growing season. Thus, the greater sensitivity of hibiscus to salinity in the springsummer season may be the result of the higher growth of plants cultivated during this season, probably because of the more favorable temperature and radiation, which permitted a severe reduction in DW, whereas the lower sensitivity in the fall-winter season may be related to the marked decrease in growth, which resulted in lower leaf DW to be affected by salinity. In fact, leaf growth of hibiscus was twice as much in summer-spring plants compared with fall-winter plants. Decreased leaf growth could have been associated with a lower transpiration rate on a whole plant basis in the fall-winter plants and a relatively lower transport of salts may be the result of reduced transpiration. However, the comparable concentration of $\mathrm{Ca}^{2+}, \mathrm{Na}^{+}$, and $\mathrm{Cl}^{-}$in the leaves suggests that other mechanisms may be affecting the tolerance of hibiscus to salinity.

According to the ranking, escallonia would be considered a susceptible species in the fallwinter and considered less sensitive in the spring-summer. This may be associated with the higher root DW during the spring-summer season, whereas in fall-winter plants, there was higher DW accumulation in the leaves. 

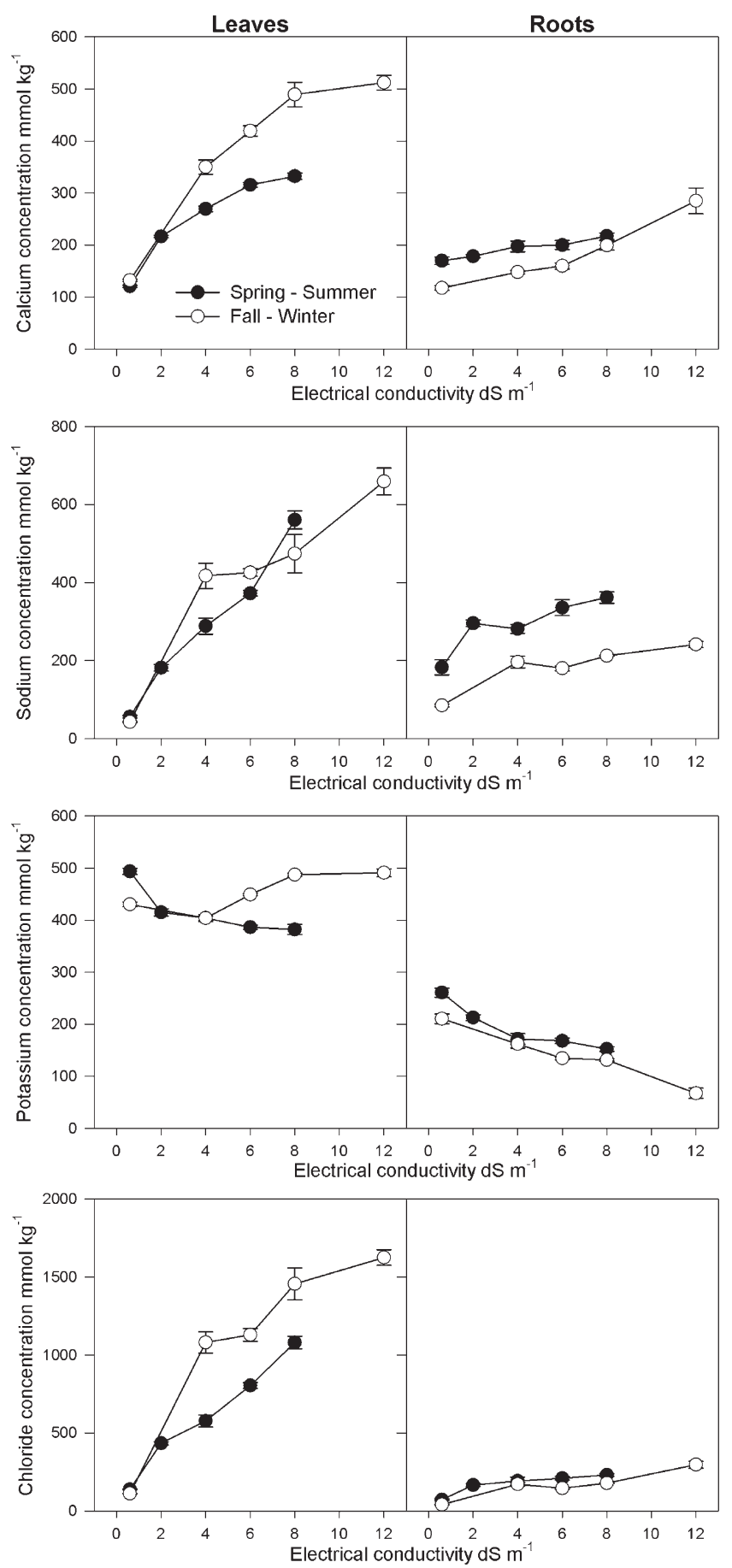

Fig. 8. Calcium, sodium, potassium, and chloride concentration in leaves and roots of escallonia plants cultivated during the spring-summer and fall-winter seasons under irrigation with water of increasing electrical conductivity. Bars represent $\operatorname{SEM}(n=5)$.

This differential distribution of DW was responsible for the higher partitioning of $\mathrm{Ca}^{2+}$, $\mathrm{Na}^{+}$, and $\mathrm{Cl}^{-}$to the roots in the spring-summer season and to the leaves in the fall-winter season. Higher root development in the springsummer allowed higher retention of $\mathrm{Ca}^{2+}$, $\mathrm{Na}^{+}$, and $\mathrm{Cl}^{-}$in the roots, preventing transport and high concentrations of toxic ions in the leaves in this season. Moya et al. (1999) reported the effect of the shoot/root ratio on $\mathrm{Cl}^{-}$uptake in sensitive and tolerant citrus cultivars. In addition to the higher partitioning of $\mathrm{Ca}^{2+}, \mathrm{Na}^{+}$, and $\mathrm{Cl}^{-}$to the leaves in the fall-winter season resulting from lower root growth, the poorer performance of escallonia when grown in the fall-winter may be the result of the higher $\mathrm{Ca}^{2+}$ and $\mathrm{Cl}^{-}$concentration in the leaves, whereas the increase in leaf $\mathrm{Na}^{+}$concentration may explain the poor response in both growing seasons. Our results are in contrast to those reported by Cassaniti et al. (2009) in that Escallonia rubra was rated as moderately salt-tolerant, largely as a result of its ability to retain more $\mathrm{Na}^{+}$in the roots than in the leaves. In general, $\mathrm{K}^{+}$concentration in the leaves and roots of the five selected species tended to decrease as $\mathrm{EC}_{\mathrm{iw}}$ increased probably as a result of ion competition between $\mathrm{K}^{+}$and $\mathrm{Na}^{+}$for uptake sites in the roots (Schachtman and Liu, 1999). However, in escallonia, $\mathrm{K}^{+}$leaf concentration did not exhibit marked changes in either growing season and, as a result, the $\mathrm{K}^{+} / \mathrm{Na}^{+}$ratio was not severely decreased by increases in salinity. Nonetheless, the potential maintenance of closer to optimal $\mathrm{K}^{+} / \mathrm{Na}^{+}$ratios was not enough to permit plant growth under saline irrigation. The sensitivity to high $\mathrm{EC}_{\mathrm{iw}}$ in escallonia may be related to the very high accumulation of $\mathrm{Cl}^{-}$in both growing seasons. Chloride levels in escallonia organs were surpassed only by those in boxwood.

Juniper was one of the most tolerant species to high $\mathrm{EC}_{\mathrm{iw}}$ regardless of the growing season as demonstrated by the lower slope of increasing salinity on leaf DW accumulation. Several species of juniper such as Juniperus scopulorum Sarg., J. virginiana L., and $J$. chinensis L. have been classified as either sensitive or moderately sensitive to salinity (Miyamoto, 2008). Our results indicate the growing season had an important effect on DW partitioning because juniper exhibited trends similar to those observed in escallonia, e.g., the shoot/ root ratio of fall-winter plants was 11.3 times higher than that of spring-summer plants. Thus, spring-summer plants had higher root DW, whereas leaf DW was higher in the fall-winter plants. Juniper's tolerance to salinity in both seasons was probably associated with reduced translocation of $\mathrm{Na}^{+}$to the leaves (and $\mathrm{Cl}^{-}$in the spring-summer at high $\mathrm{EC}_{\mathrm{iw}}$ ) because root concentration was higher in both seasons. The higher root DW in the springsummer together with increased retention of ions such as $\mathrm{Na}^{+}$and $\mathrm{Cl}^{-}$in this organ may have protected actively photosynthesizing leaves from damage as a result of these potentially toxic ions. Perennial species such as juniper rely on salt retention in the roots as a chief mechanism for tolerance to salinity because leaves have to live for 1 year or longer (Munns, 2002). Marigold is another ornamental species reported to exhibit $\mathrm{Na}^{+}$exclusion to the roots (Jarecki et al., 2005; Valdez-Aguilar et al., 2009).

Hawthorn was ranked a sensitive species in both growing seasons. Growing season affected the shoot/root ratio in the springsummer plants, as demonstrated by the higher root DW compared with fall-winter plants. Higher root development during the springsummer could be responsible for a higher uptake of $\mathrm{Ca}^{2+}, \mathrm{Na}^{+}$, and $\mathrm{Cl}^{-}$; nonetheless, accumulation of toxic concentrations in the leaves was prevented by storing more quantities of these ions, especially $\mathrm{Cl}^{-}$, in the larger roots, as suggested by the reduced partitioning to the leaves. Although hawthorn also exhibited a mechanism comparable to that of juniper in the spring-summer, it was unable to sustain leaf growth, suggesting that this species has a high sensitivity to salinity although less $\mathrm{Ca}^{2+}$, $\mathrm{Na}^{+}$, and $\mathrm{Cl}^{-}$were transported and accumulated in the leaves. This also suggests that other mechanisms such as lower compartmentalization in the vacuoles may be responsible for the higher sensitivity of hawthorn. The 

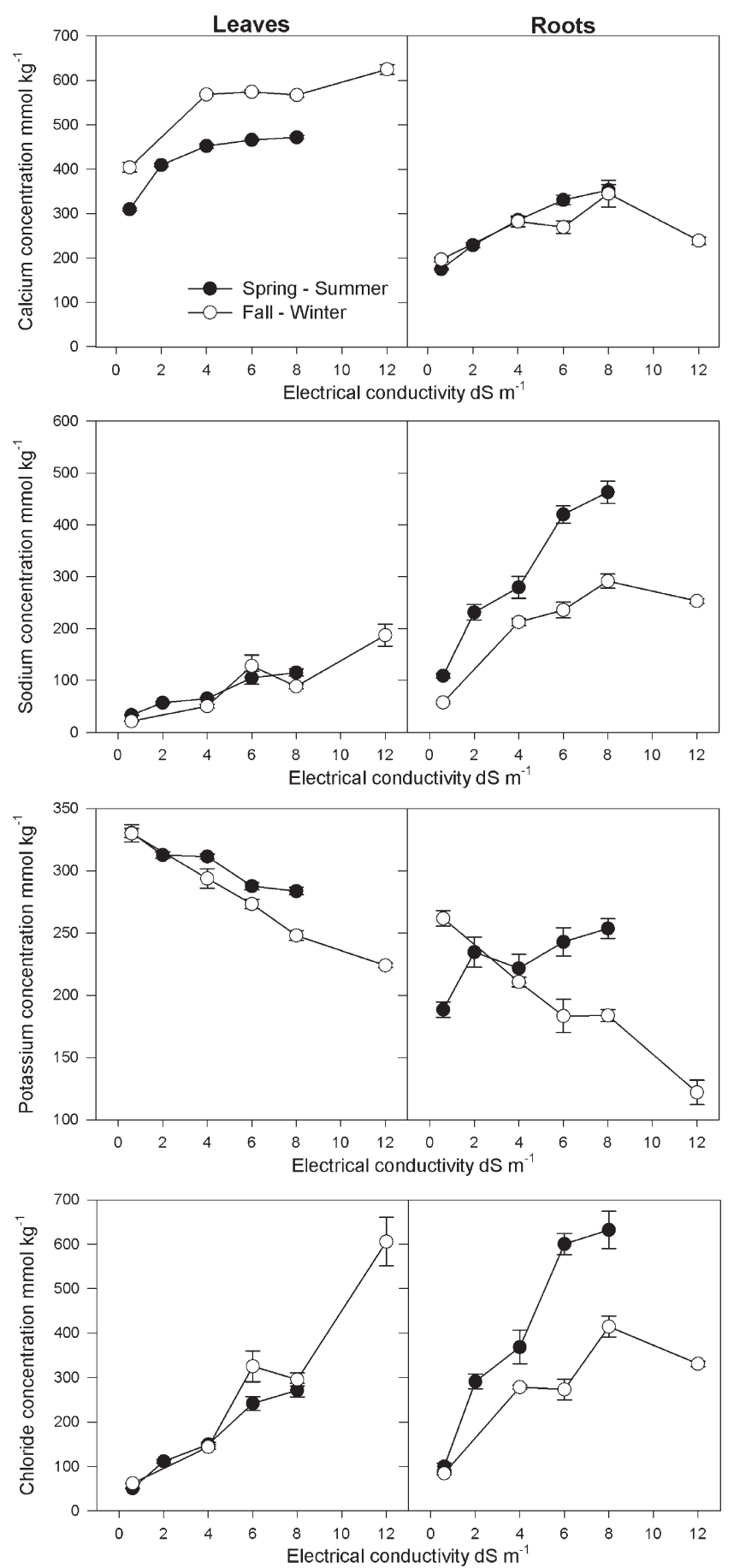

Fig. 9. Calcium, sodium, potassium, and chloride concentration in leaves and roots of juniper plants cultivated during the spring-summer and fall-winter seasons under irrigation with water of increasing electrical conductivity. Bars represent $\operatorname{SEM}(\mathrm{n}=5)$.

susceptibility detected in fall-winter plants may be the result of the increased concentration of $\mathrm{Ca}^{2+}, \mathrm{Na}^{+}$, and $\mathrm{Cl}^{-}$when $\mathrm{EC}$ was $8 \mathrm{dS} \cdot \mathrm{m}^{-1}$ or higher. In spring-summer, hawthorn tended to have larger $\mathrm{Na}^{+}$and $\mathrm{Cl}^{-}$concentrations in root tissues than in the leaves, suggesting a potential exclusion capacity. However, in the fall-winter season, leaves had higher concentrations of these ions, especially $\mathrm{Cl}^{-}$and $\mathrm{Na}^{+}$, when EC was $8 \mathrm{dS} \cdot \mathrm{m}^{-1}$ or higher, suggesting an apparent loss of exclusion capacity in the fall-winter, which may be associated with lower tempera- tures and/or daylength duration. Seasonal variation in ion uptake was also demonstrated by Duman et al. (2007) who reported that in aquatic species such as Phragmites australis (Cav.) Trin. ex. Steud and Schoenoplectus lacustris (L.) Palla, there was a variation in heavy metal concentration in plant parts as a result of environmental differences, including metabolic factors and dilution of metal contents resulting from growth. Likewise, Storey and Walker (1999) reported that in citrus, there are different loading curves for $\mathrm{Na}^{+}$and $\mathrm{Cl}^{-}$; therefore, it is possible that uptake of salts may vary with season and environmental conditions. Differential uptake and/or concentration of salts resulting from season effect was also exhibited in escallonia $\left(\mathrm{Ca}^{2+}\right.$ and $\left.\mathrm{Cl}^{-}\right)$, juniper $\left(\mathrm{Ca}^{2+}\right)$, and boxwood $\left(\mathrm{Ca}^{2+}, \mathrm{Na}^{+}\right.$, and $\left.\mathrm{Cl}^{-}\right)$.

Boxwood was among the species that exhibited acceptable tolerance in terms of leaf DW reduction in both growing seasons. Miyamoto (2008) rated Buxus microphylla Siebold, \& Zucc. as moderately sensitive to salinity because plants showed acceptable growth when EC of the saturation extract was between 3 and $6 \mathrm{dS} \cdot \mathrm{m}^{-1}$. This conclusion was not confirmed by the results of our study inasmuch as when other criteria such as visual quality of plants was taken into account, boxwood was rated as sensitive as a result of noticeable leaf bronzing at $\mathrm{EC}_{\mathrm{iw}}$ of $2 \mathrm{dS} \cdot \mathrm{m}^{-1}$ and higher. The high sensitivity of boxwood may be the result of the low capacity to compartmentalize $\mathrm{Na}^{+}$ and $\mathrm{Cl}^{-}$in the roots as demonstrated by the high concentration of $\mathrm{Na}^{+}$and $\mathrm{Cl}^{-}$in the leaves, which were the highest of all the five species studied.

Results described for boxwood emphasize that other plant growth responses should be considered for ranking the tolerance to salinity in ornamental species (Cassaniti et al., 2009; Francois, 1982). In the present study, we evaluated the effect of increasing salinity on visual quality of plants grown in the springsummer season. The most impacted visual attributes of plants observed was leaf bronzing, which made some species that had a good tolerance in terms of leaf DW unsuitable for marketing. On the other hand, other species that responded with high reductions in leaf DW were not visually affected. Bronzing may have been the result of high leaf concentrations of $\mathrm{Na}^{+}$or $\mathrm{Cl}^{-}$, like in boxwood, causing direct toxicity resulting from ion specific effects (Munns and Tester, 2008). The threshold $\mathrm{EC}_{\mathrm{iw}}$ at which visual quality was affected allows the following ranking (higher to lower tolerance):

$$
\begin{aligned}
& \text { Hibiscus }>\text { Juniper }>\text { Escallonia }> \\
& \left(5.44 \mathrm{dS} \cdot \mathrm{m}^{-1}\right)\left(4.83 \mathrm{dS} \cdot \mathrm{m}^{-1}\right)\left(2.98 \mathrm{dS} \cdot \mathrm{m}^{-1}\right) \\
& \text { Hawthorn }>\text { Boxwood } \\
& \left(1.99 \mathrm{dS} \cdot \mathrm{m}^{-1}\right) \quad\left(0.60 \mathrm{dS} \cdot \mathrm{m}^{-1}\right)
\end{aligned}
$$

Thus, despite hibiscus exhibiting the largest reduction in leaf DW when grown in the spring-summer, the visual quality was maintained even at $\mathrm{EC}_{\mathrm{iw}}$ as high as $5.44 \mathrm{dS} \cdot \mathrm{m}^{-1}$. Juniper, with the lowest reduction in leaf $\mathrm{DW}$, was the one with the highest tolerance to $\mathrm{EC}_{\mathrm{iw}}$ and the one whose visual quality was unaffected when $\mathrm{EC}_{\mathrm{iw}}$ was $4.83 \mathrm{dS} \cdot \mathrm{m}^{-1}$. In terms of visual quality, hawthorn and escallonia were moderately tolerant because their visual quality was affected only when EC was higher than 1.99 and $2.98 \mathrm{dS} \cdot \mathrm{m}^{-1}$, respectively. Boxwood showed a high sensitivity to salinity because visual quality was negatively affected at concentrations of 0.6 $\mathrm{dS} \cdot \mathrm{m}^{-1}$ or greater. The corresponding $\mathrm{EC}_{\mathrm{dw}}$, as estimated by linear regression, for the respective visual quality thresholds would be $11.67 \mathrm{dS} \cdot \mathrm{m}^{-1}$ for hibiscus, $10.48 \mathrm{dS} \cdot \mathrm{m}^{-1}$ 

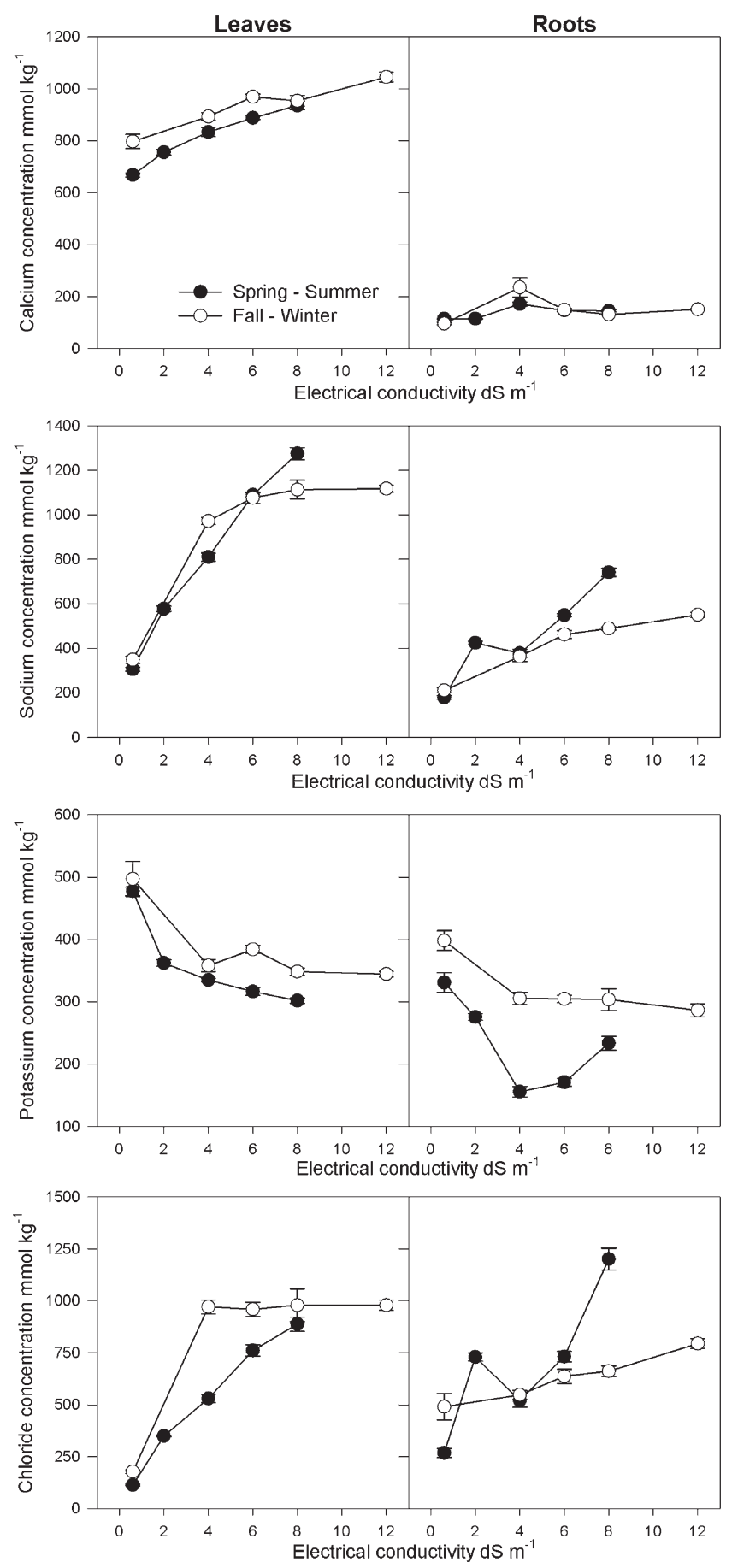

Fig. 10. Calcium, sodium, potassium, and chloride concentration in leaves and roots of hibiscus plants cultivated during the spring-summer and fall-winter seasons under irrigation with water of increasing electrical conductivity. Bars represent SEM $(n=5)$.

for juniper, $6.87 \mathrm{dS} \cdot \mathrm{m}^{-1}$ for escallonia, 4.94 $\mathrm{dS} \cdot \mathrm{m}^{-1}$ for hawthorn, and $2.23 \mathrm{dS} \cdot \mathrm{m}^{-1}$ for boxwood. Using the U.S. Salinity Laboratory classification system of salinity tolerance in ornamental species based on $\mathrm{EC}$ of saturation extract (Miyamoto, 2008) as equivalent to EC of drainage water, the selected ornamental species would be ranked as sensitive (0 to 3 $\mathrm{dS} \cdot \mathrm{m}^{-1}$ ) for boxwood, moderately sensitive ( 3 to $6 \mathrm{dS} \cdot \mathrm{m}^{-1}$ ) for hawthorn, moderately tolerant $\left(6\right.$ to $\left.8 \mathrm{dS} \cdot \mathrm{m}^{-1}\right)$ for escallonia, and highly tolerant (greater than $10 \mathrm{dS} \cdot \mathrm{m}^{-1}$ ) for hibiscus and juniper.

\section{Conclusions}

The five selected species grown in the container production phase exhibited differential responses to increasing salinity in irrigation water. Growth was affected by salinity and growing season because DW accumulation was reduced by increasing $\mathrm{EC}_{\mathrm{iw}}$, whereas roots of hawthorn, juniper, and escallonia accumulated more DW during the spring-summer and leaves accumulated more DW in the fallwinter. Higher root DW allowed the allocation of $\mathrm{Ca}^{2+}, \mathrm{Na}^{+}$, and $\mathrm{Cl}^{-}$to this plant part, prevent- ing toxic concentrations in the leaves. This mechanism as well as with $\mathrm{Na}^{+}$and $\mathrm{Cl}^{-}$retention by the roots were both especially efficient in juniper and as a result, this species was rated as the most tolerant in terms of growth and visual quality. Boxwood exhibited acceptable tolerance in terms of growth, but visual quality of the final product was severely hampered. Growth of hibiscus was the most severely reduced when grown in spring-summer, however, it was rated as the most tolerant species in terms of visual quality, although the toxic concentrations and allocation of $\mathrm{Ca}^{2+}$, $\mathrm{Na}^{+}$, and $\mathrm{Cl}^{-}$in leaves suggests salt compartmentalization.

\section{Literature Cited}

Ammary, B.Y. 2007. Wastewater reuse in Jordan Present status and future plans. Desalination 211:164-176.

Asano, T. 2002. Water from (waste)water-The dependable water resource. Water Sci. Technol. 45:24-33.

Black, R.J. 2003. Salt-tolerant plants for Florida. Department of Environmental Horticulture, Florida Cooperative Extension Service, Institute of Food and Agricultural Sciences, University of Florida. ENH26.

Cassaniti, C., C. Leonardo, and T.J. Flowers. 2009 The effects of sodium chloride on ornamental shrubs. Sci. Hort. 122:586-593.

Cramer, G.R., A. Lauchli, and V.S. Polito. 1985 Displacement of $\mathrm{Ca}^{2+}$ by $\mathrm{Na}^{+}$from the plasmalemma of root-cells-A primary response to salt stress. Plant Physiol. 79:207-211.

Duman, F., M. Cicek, and G. Sezen. 2007. Seasonal changes in metal accumulation and distribution in common club rush (Schoenoplectus lacustris) and common reed (Phragmites australis). Ecotoxicology 16:457-463.

Francois, L.E. 1982. Salt tolerance of eight ornamental tree species. J. Amer. Soc. Hort. Sci. 107: 66-68.

Jarecki, M.K., C. Chong, and R.P. Voroney. 2005 Evaluation of compost leachates for plant growth in hydroponic culture. J. Plant Nutr. 28: 651-667.

Kjelgren, R., L. Rupp, and D. Kilgren. 2000. Water conservation in urban landscapes. HortScience 35:1037-1040.

Lindsey, P., M.A. Harivandi, and G. Setka. 1998. Recycled landscape irrigation water and ornamental plant compatibility study. Slosson Report 1996-1998. 29 Feb. 2008. <http://groups. ucanr.org/slosson/documents/1995-19982110. pdf $>$.

Loram, A., J. Tratalos, P.H. Warren, and K.J. Gaston. 2007. Urban domestic gardens (X): The extent \& structure of the resource in five major cities. Landscape Ecol. 22:601-615.

Miyamoto, S. 2008. Salt tolerance of landscape plants common to the southwest. Texas AgriLife Research and Extension Center. Texas A\&M University System in cooperation with Texas Water Resource Institute and El Paso Water Utilities, El Paso, TX. TR-2008-316.

Moya, J.L., E. Primo-Millo, and M. Talon. 1999. Morphological factors determining salt tolerance in citrus seedlings: The shoot to root ratio modulates passive root uptake of chloride ions and their accumulation in leaves. Plant Cell Environ. 22:1425-1433.

Munns, R. 2002. Comparative physiology of salt and water stress. Plant Cell Environ. 25:239250 . 
Munns, R. and M. Tester. 2008. Mechanisms of salinity tolerance. Annu. Rev. Plant Biol. 59:651-681.

Niu, G. and D.S. Rodriguez. 2006. Relative salt tolerance of selected herbaceous perennials and groundcovers. Sci. Hort. 110:352-358.

Qian, Y.L. and B. Mechan. 2005. Long term effects of recycled wastewater irrigation on soil chemical properties on golf course fairways. Agron. J. 97:717-721.

SAS Institute, Inc. 2001. SAS/STAT software changes and enhancements through release 8.0.2. SAS Institute, Cary, NC.

Schachtman, D. and W. Liu. 1999. Molecular pieces to the puzzle of the interaction between potassium and sodium in plants. Trends Plant Sci. 4:281-287.

Sovocool, K.A., M. Morgan, and D. Bennett. 2006. An in-depth investigation of xeriscape as a water conservation measure. American Water Works Association Journal 98:81-93.

Storey, R. and R.R. Walker. 1999. Citrus and salinity. Sci. Hort. 78:39-81.

USEPA. 1992. Manual: Guidelines for water reuse. USEPA Rep. 625/R-92/004. USEPA, Washington, DC.

Valdez-Aguilar, L.A., C.M. Grieve, J. Poss, and D. Layfield. 2009. Salinity and alkaline $\mathrm{pH}$ of irrigation water affect growth of marigold plants: II. Mineral ion relations. HortScience 44:1726-1735.

van Genuchten, M.Th. 1983. Research Report No. 120, U.S. Salinity Laboratory, USDA-ARS, Riverside, California, $50 \mathrm{p}$.

Wakeel, A., F. Abd-El-Motagally, D. Steffens, and S. Schubert. 2009. Sodium-induced calcium deficiency in sugar beet during substitution of potassium by sodium. J. Plant Nutr. Soil Sci. 172:254-260

Zollinger, N., R. Koenig, T. Cerny-Koenig, and R. Kjelgren. 2007. Relative salinity tolerance of intermountain western United States native herbaceous perennials. HortScience 42:529-534. 